\title{
"KAJIAN HUKUM TERHADAP SERTIPIKAT HAK TANGGUNGAN ROYA YANG HILANG PADA KANTOR PERTANAHAN KOTA SAMARINDA”.'
}

\author{
Iswananta, S.H dan Hj. Wahyuni Safitri, S.H.,M.Hum.
}

\begin{abstract}
ABSTRAK
Pengertian Roya secara umum adalah suatu prosedur untuk melakukan pencoretan catatan beban hak tanggungan pada buku tanah dan sertifikat tanah yang dilakukan oleh Kantor Pertanahan dimana hak tanggungan itu didaftarkan, apabila debitur telah melunasi hutangnya kepada kreditur. Dalam melaksanakan roya kreditur (Bank) mengembalikan sertifikat hak tanggungan dan sertifikat tanah yang bersangkutan ke Kantor Pertanahan disertai pernyataan tertulis untuk menghapus atau roya atas hak tanggungan yang melekat. Namun pada prakteknya tidak jarang dijumpai sertifikat hak tanggungan yang dimiliki debitur yang telah melunasi hutangnya kepada kreditur hilang oleh karena pengarsipan dari pihak kreditur yang kurang baik ataupun karena terjadinya mutasi petugas kredit yang menangani secara langsung. Keadaan ini tentunya akan menyulitkan debitur ketika hendak melakukan proses roya ke Kantor Pertanahan, oleh karenanya bagimana pertanggungjawaban atas hilangnya sertipikat hak tanggungan oleh kreditur (Bank).
\end{abstract}

Kata kunci: Hak Tanggungan, Roya beserta Prosesnya.

\begin{abstract}
Understanding of Roya is a procedure to carry out the removal of a load record security rights in land books and certificates of land by the Land Office where a security interest is registered, if the debtor has paid the debt or a dependent to creditors, In carrying out the roya creditor (Bank) returns encumbrance certificate and the certificate of the land in question to the Land Office accompanied by a written statement to remove or roya on mortgages attached. Practice, it is not rare encumbrance certificate owned by the debtor's debts to creditors lost in the filing of the creditors who are less well because of mutation or loan officers who deal directly. This situation will certainly complicate the debtor when they wanted to make the process of Roya to the Land Office, therefore, how the liability for the loss of the certificate encumbrance by a creditor (the Bank).
\end{abstract}

Keywords: Mortgage, Roya and process.

\section{BAB I \\ PENDAHULUAN}

\section{A. Latar Belakang}

Meningkatnya pembangunan nasional bertitik berat pada bidang ekonomi, yang mengelola kekuatan potensi ekonomi menjadi kekuatan ekonomi riil dengan memanfaatkan sarana permodalan yang ada sebagai sarana pendukung utama dalam pembangunan tersebut membutuhkan penyediaan dana yang cukup besar.

Peran masyarakat dalam pembiayaan akan semakin besar, hal tersebut disebabkan dana yang diperlukan dalam pembangunan berasal atau dihimpun dari 
masyarakat melalui perbankan, yang kemudian disalurkan kembali kepada masyarakat berupa pemberian kredit, guna menuju kearah yang lebih produktif. Pembiayaan tersebut menjamin penyalurannya sehingga menjadi sumber pembiayaan yang riil, maka dana yang bersumber pada perkreditan merupakan sarana yang mutlak diperlukan. Saat ini, bank dan lembaga keuangan lainnya berfungsi antara lain untuk memberikan kredit. Kredit ialah suatu fasilitas untuk memperoleh pinjaman uang. Pinjaman uang ini akan menyebabkan timbulnya utang, yang harus dibayar oleh debitur menurut syarat-syarat yang ditetapkan dalam suatu perjanjian pinjaman atau persetujuan untuk membuka kredit.

Salah satu barang jaminan untuk pembayaran utang yang paling disukai oleh lembaga keuangan yang memberikan fasilitas kredit adalah tanah. Tentu saja tidak semua tanah memiliki sifat atau dalam keadaan sebagai disebut di atas.Tanah yang sukar dijual harganya terus menurun, mudah digelapkan tidak mempunyai tanda bukti hak dan tidak dapat dibebani hak tanggungan, biasanya tidak dapat diterima oleh kreditur sebagai jaminan pembayaran uang.

Agar tanah sebagai jaminan kredit dapat memberikan kepastian hukum terhadap kreditur maka diperlukan sebuah lembaga jaminan, dimana hal yang dimaksudkan ini adalah lembaga jaminan hak tanggungan yang mampu memberikan jaminan perlindungan hukum baik kepada debitur maupun kreditur.

Lembaga jaminan hak tanggungan digunakan untuk mengikat objek jaminan utang yang berupa tanah atau benda-benda yang berkaitan dengan tanah yang bersangkutan. hak tanggungan sebagaimana dimaksud telah diatur dalam Undangundang Nomor 4 Tahun 1996 tentang Hak Tanggungan Atas Tanah Beserta BendaBenda Yang Berkaitan Dengan Tanah (Undang-Undang Hak Tanggungan (UUHT)).

Undang-undang Hak Tanggungan Nomor 4 Tahun 1996 tersebut, memuat ketentuan-ketentuan yang mendasar mengenai hakekat hak tanggungan maupun ketentuan-ketentuan mengenai prosedur operasional pemberian dan pendaftarannya, memberikan perlindungan hukum yang kuat dan kepastian hukum yang seimbang bagi para kreditur dan debitur serta pengaturan yang lengkap mengenai syarat-syarat untuk perlindungan barang jaminan. Pengaturan sebagaimana dimaksud meliputi :

1. Obyek hak tanggungan

2. Pemberi dan pemegang hak tanggungan

3. Tata cara pemberian, pendaftaran, peralihan dan hapusnya hak tanggungan.

4. Eksekusi hak tanggungan

5. Pencoretan (roya) hak tanggungan

6. Sanksi administratif

Sehubungan dengan uraian diatas, dapat dijelaskan bahwa proses pernbebanan hak tanggungan dilaksanakan melalui 2 (dua) tahap kegiatan yaitu:

1. Tahap pemberian hak tanggungan, yaitu dengan dibuatnya Akta Pemberian Hak Tanggungan (APHT) oleh Pejabat Pembuat Akta Tanah (PPAT) yang didahului dengan perjanjian utang piutang yang dijamin.

2. Tahap pendaftarannya oleh Kantor Pertanahan yang merupakan saat lahirnya hak tanggungan yang dibebankan. ${ }^{1}$

Untuk mendapatkan gambaran yang jelas, maka perlu diketahui proses pembuatan Akta Pemberian Hak Tanggungan (APHT), kemudian proses

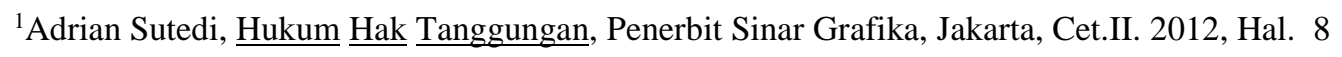


pendaftarannya sampai dengan lahirnya hak tanggungan, kemudian setelah debitur dapat melunasi hutang-hutangnya, dilakukan proses roya hak tanggungan. Sebagaimana diketahui bahwa Akta Pemberian Hak Tanggungan (APHT) dibuat dihadapan Pejabat Pembuat Akta Tanah (PPAT) yang berwenang sesuai dengan wilayah kerja PPAT, jadi APHT merupakan akta otentik. Sebagai akta otentik, mempunyai dan harus memenuhi persyaratan sebagaimana ditentukan dalam Undang-undang Hak Tanggungan.

Setelah Akta Pemberian Hak Tanggungan (APHT) dibuat oleh para pihak yang berkepentingan, maka dalam waktu 7 (tujuh) hari kerja wajib didaftarkan ke Kantor Pertanahan setempat lengkap dengan dokumen pendukungnya, kemudian dalam waktu 7 (tujuh) hari kerja setelah diterimanya pendaftaran secara lengkap, Kantor Pertanahan wajib untuk menerbitkan sertipikat hak tanggungan. Dengan dibuatnya sertifikat hak tanggungan, maka akan terpenuhinya asas publisitas yang akan memberikan perlindungan kepada semua pihak yang terlibat dalam hak tanggungan. Apabila hak tanggungan hapus karena pelunasan utang oleh debitur kepada kreditur, maka hapusnya hak tanggungan harus dilakukan dengan mengadakan pencoretan atau roya di Kantor Pertanahan dimana hak tanggungan tersebut didaftarkan.

Mengenai roya atas pencoretan catatan beban ini diatur dalam Pasal 22 ayat (1) UUHT yang berbunyi sebagai berikut : "hak tanggungan hapus sebagaimana dimaksud pada pasal 18, Kantor Pertanahan mencoret catatan hak tanggungan tersebut pada buku tanah dan sertifikat hak atas tanahnya". Pengertian Roya secara umum adalah suatu prosedur untuk melakukan pencoretan catatan beban hak tanggungan pada buku tanah dan sertifikat tanah yang dilakukan oleh Kantor Pertanahan dimana hak tanggungan itu didaftarkan, apabila debitur telah melunasi hutangnya kepada kreditur. Dalam melaksanakan roya ini kreditur (Bank) mengembalikan sertifikat hak tanggungan dan sertifikat tanah yang bersangkutan ke Kantor Pertanahan disertai pernyataan tertulis untuk menghapus atau roya atas hak tanggungan yang melekat.

Namun dalam prakteknya tak jarang dijumpai sertifikat hak tanggungan yang dimiliki debitur yang telah melunasi hutangnya kepada kreditur hilang oleh karena pengarsipan dari pihak kreditur yang kurang baik ataupun karena terjadinya mutasi petugas kredit yang menanganinya langsung. Keadaan ini tentunya akan menyulitkan debitur ketika hendak melakukan proses roya ke Kantor Pertanahan.

\section{B. Permasalahan}

Berdasarkan uraian sebagaimana dijelaskan dalam latar belakang diatas, maka penulis merumuskan masalah yang diangkat dalam Penulisan Karya Ilmiah ini adalah sebagai berikut:

1. Bagaimanakah Pertanggungjawaban atas hilangnya sertipikat hak tanggungan oleh kreditur (Bank)?

2. Bagaimanakah pelaksanaan proses roya pada kantor pertanahan Kota Samarinda terhadap sertipikat hak tanggungan yang hilang?

\section{Tujuan Penelitian}

Berdasarkan latar belakang dan permasalahan yang telah dikemukakan maka tujuan penelitian ini adalah:

a. Untuk mengetahui Bagaimanakah pertanggungjawaban atas hilangnya sertipikat hak tanggungan oleh kreditur (Bank). 
b. Untuk mengetahui bagaimana pelaksanaan proses roya pada kantor pertanahan Kota Samarinda terhadap sertipikat hak tanggungan yang hilang.

\section{Manfaat Penelitian}

\section{Kegunaan Praktis}

a. Untuk memperluas wawasan dan pengetahuan dalam memahami roya hak tanggungan dalam prakteknya pada suatu Kantor Pertanahan. Serta dapat menambah pengetahuan penulis mengenai bagaimana prosedur pelaksanaan roya di Kantor Pertanahan Samarinda yang sertipikat hak tanggungannya hilang.

b. Diharapkan dapat membantu debitur agar lebih memahami tata cara roya hak tanggungan dan dampaknya apabila sertipikat hak tanggungan hilang pada saat mau proses roya di Kantor Pertanahan Kota Samarinda.

\section{Kegunaan Teoritis}

Diharapkan dapat berguna bagi perkembangan ilmu hukum, khususnya hukum pertanahan dan hukum jaminan yang berhubungan dengan pengaturanpengaturan mengenai roya hak tanggungan dengan segala permasalahannya.

\section{BAB II \\ METODE PENELITIAN}

\section{Jenis Penelitian}

Penelitian yuridis normatif membahas doktrin-doktrin atau asas-asas dalam ilmu hukum serta melihat sinkronisasi suatu aturan dengan aturan lainnya secara hierarki. Untuk menyelesaikan isu mengenai masalah hukum mengenai objek sertipikat hak tanggungan yang hilang dalam proses roya dan sekaligus bagaimana pertangung jawaban pihak kreditur (bank) terhadap hilangnya sertipikat hak tanggugan tersebut, peneliti memerlukan sumber-sumber penelitian yang disebut bahan hukum, baik bahan hukum primer maupun sekunder.

\section{Sumber Data}

1). Bahan hukum primer adalah data normatif terutama yang bersumber dari perundang-undangan, buku-buku atau literatur-literatur sehubungan dengan hak tanggugan, hukum perjanjian dan hukum kenotariatan. Majalah, jurnal artikel media massa maupun sebagai bahan bacaan kuliah dan kepustakaan lainnya.

2). Bahan hukum sekunder adalah data empiris yang diperoleh langsung dari sumber data yang diperoleh melalui hasil wawancara kepada staf yang khusus menangani roya di kantor Pertanahan Kota Samarinda

3). Bahan hukum tertier adalah petunjuk atau penjelasan mengenai bahan hukum primer dan bahan hukum sekunder yang berasal dari Kamus dan Ensiklopedia Hukum.

\section{Alat Pengumpulan data}

a. Penelitian kepusatakaan, yakni pengumpulan data yang diperlukan dengan melakukan kepustakaan melalui Peraturan Perundang-undangan, majalah, literatur, internet, buku-buku, kamus bahasa, kamus hukum dan bahan kepustakaan lainnya terkait masalah yang diteliti.

b. Penelitian dilapangan, yakni pengumpulan data dengan melakukan wawancara Pejabat diKantor Pertanahan Kota Samarinda yang bertugas menangani Roya.

\section{Analisis Data}


Analisis data yang dilakukan menggunakan metode analisis deskriptif kualitatif, yaitu sebagai prosedur penelitian yang menghasilkan data deskriptif, berupa kata-kata tertulis atau lisan dari orang-orang dan perilaku yang dapat diamati. Pendekatan ini diarahkan pada latar belakang dari individu tersebut secara holistik (utuh). Jadi dalam hal ini, tidak boleh mengisolasikan individu atau institusi ke dalam variabel atau hipotesis, tetapi perlu memandangnya sebagai bagian dari suatu keutuhan.

\section{BAB III \\ PEMBAHASAN}

\section{A. PertanggungJawaban atas hilangnya Sertipikat Hak Tanggungan oleh kreditur (Bank)}

Bank menjadi tumpuan dari hampir semua pusat kegiatan perusahaan dan perdagangan baik nasional maupun international. Perbankan juga merupakan insting dari sistem keuangan setiap negara. Bank juga sebagai lembaga keuangan yang menjadi sarana bagi perusahaan, badan-badan pemerintah, swasta maupun perorangan dalam menyimpan dananya.

Kunci keberhasilan bank adalah bagaimana bank tersebut bisa merebut hati masyarakat sehingga peranannya berjalan dengan baik. Bank adalah perantara keuangan masyarakat yaitu perantara dari mereka yang kelebihan uang dengan mereka yang kekurangan uang. Kalau peranan ini berjalan dengan baik barulah bank dikatakan sukses.

Pelanggaran hak Debitur oleh Krediitur (bank) dapat diselesaikan melalui jalur hukum. Namun ketika kita kembali sadarkan terhadap nilai-nilai Negara hukum Pancasila dan Undang-Undang Dasar 1945 yang mengedepankan asas musyawarah, forum mediasi merupakan dimensi yang juga penting.

Artinya, ketika sengketa perbankan masih dapat diselesaikan secara baik dan tetap menguntungkan kedua belak pihak, maka jalur hukum atau pengadilan dapat dikesampingkan/dihentikan. Hal ini juga terkait dengan prinsip penyelesaian sengketa secara murah, sederhana dan cepat.

Hadirnya upaya tersebut tentu tidak terlepas dari hubungan timbal balik antara Debitur dan Kreditur (bank), baik itu nasabah penyimpan dalam bentuk tabungan maupun pengajuan Kredit ke Bank dengan pemberian Hak tanggungan. serta kewajiban-kewajiban Debitur untuk memenuhi ketentuan sistem administrasi tertentu apabila hendak mengambil atau menyimpan uang.

Selain itu sebagai upaya peningkatan dan pemberdayaan tentu bank sebagai pelaku usaha harus memberikan layanan penyelesaian dan infrastruktur atas berbagai keluhan dan pengaduan dari pihak Debitur. Media penyelesaian ini juga harus memenuhi standar waktu dan pelayanan Artinya dapat berlaku secara efektif dan efesien.

Bank Indonesia sebagai pemegang otoritas perbankan Indonesia dalam upaya memenuhi standar tersebut juga telah memprioritaskan program-program terkait perlindungan nasabah (debitur), termasuk penanganan pengaduan dari Debitur, termasuk penanganan perbankanan pembentukan lembaga mediasi perbankan independen.

Dalam ranah hukum, seorang tentu harus bertanggung jawab terhadap kerugian yang diakibatkan oleh perbuatan yang bertentangan dengan hukum dari orang lain. 
hal ini disebut tanggungjawab kwalitatif, yaitu orang yang bertanggung jawab karena orang itu memiliki suatu kwalitas tertentu.

Sesuai dengan penerapan hukum di Indonesia, seorang konsumen yang dilakukan oleh pelaku usaha, termasuk nasabah kepada bank, dapat menggugat pihak yang menimbulkan kerugian atas produk dan jasanya tersebut. Kwalifikasi gugatan yang lazim adalah wanprestasi atau perbuatan melawan hukum.

Dalam gugatan adanya wanprestasi, maka terdapat hubungan kontraktual antara konsumen dan pelaku usaha/produsen. Kerugian yang dialami oleh debitur tidak lain adalah karena tidak dilaksanakan prestasi oleh bank sebagai pelaku usaha.

Apabila tidak terdapat hubungan kontraktual antara nasabah dan bank, maka tidak ada tanggung jawab (hukum) pelaku usaha nasabah. Hal inilah yang dikenal dengan doktrin yang mengandung prinsip "tidak ada hubungan kontraktual, tidak ada tanggung jawab".

Sedangkan dalam gugatan berdasarkan perbuatan melawan hukum, hubungan kontraktual tidaklah disyaratkan. Dalam hal ini nasabah haruslah membuktikan adanya unsur-unsur:

1. Adanya perbuatan melawan hukum,

2. Adanya kesalahan/kelalaian pelaku usaha,

3. Adanya kerugian yang dialami oleh Debitur,

4. Adanya hubungan kausal antara perbuatan melawan hukum dan kerugian yang dialami oleh Debitur.

Pada Undang-undang No 8 tahun 1999 tentang Perlindungan Konsumen (UUPK), dalam konteks pertanggung jawaban pelaku usaha atas gugatan debitur ini, diatur beberapa ketentuan :

1. Pertanggung jawaban Pidana Korporasi

Subjek hukum tindak pidana UndangUndang Perlindungan Konsumen adalah pelaku usaha. Pelaku usaha yang termasuk dalam pengertian ini adalah perusahaan, korporasi, BUMN, koperasi, impotir, pedagang, distributor, dan lain-lain. Artinya, bank pemerintah maupun swasta, termasuk Bank Perkreditan termasuk kategori ini.

2. Hak gugat Lembaga Konsumen

Lembaga konsumen, atas nama kepentingan konsumen, dapat mengajukan gugatan atas pelanggaran yang dapat dilakukan pelaku usaha yang merugikan kepentingan konsumen (Pasal 46 ayat (1) huruf c UUPK). Disini lembaga konsumen mempunyai hak gugat ( legal standing to sue ) kepada pelaku usaha, lepas ada atau tidak ada surat kuasa dari konsumen yang dirugikan.

3. Gugatan Kepentingan kelompok

Terhadap sengketa konsumen yang melibatkan konsumen dalam jumlah besar/missal, padahal ini persoalaan menyangkut hal yang sama, konsumen dapat mengajukan gugatan kepentingan kelompok ( class action ) kepada pelaku usaha (Pasal 46 ayat (1) huruf b UUPK).

4. Beban Pembuktian terbalik

Pelaku usaha bertanggung jawab memberikan ganti rugi atas kerusakan, atau kehilangan, dan/atau kerugian konsumen akibat menggunakan produk atau jasa yang dihasilkan atau diperdagangkan (Pasal 19 ayat (1) UUPK).

Ganti rugi dapat berupa pengembalian uang atau penggantian barang dan/atau jasa yang sejenis atau setara nilainya, atau perawatan kesehatan dan/atau 
pemberian santunan yang sesuai dengan ketentuan peraturan PerundangUndangan yang berlaku.

Ketentuan ini tidak berlaku apabila pelaku usaha dapat membuktikan bahwa kerugian tersebut merupakan atau sebagai akibat kesalahan konsumen. Sehingga, pembuktian terhadap ada tidaknya unsur kesalahan dalam gugatan- gugatan ganti rugi, merupakan beban dan tanggung jawab pelaku usaha (Pasal 28 UUPK).

Pada umumnya Debitur akan mengalami kesulitan untuk membuktikan unsur ada tidaknya kesalahan atau kelalaian pelaku usaha. Untuk itulah dianut doktrin productliability, dimana tergugat dianggap telah bermasalah (presumption of guilty) kecuali ia mampu membuktikan bahwa ia tidak melakukan kelalaian atau kesalahan. Peraturan Bank Indonesia Nomor 5/8/PBI/2003 tentang Penerapan Manajemen Risiko Bagi Bank Umum (selanjutnya disingkat PBI No. 5/8/ PBI/2003). Perlunya manajemen resiko ini ada kaitannya dengan kepercayaan masyarakat terhadap dunia perbankan, sehingga perlu menghindari potensi terjadinya suatu peristiwa ( events ) yang dapat menimbulkan kerugian bank.

\section{B. Pelaksanaan Proses Roya Pada Kantor Pertanahan Kota Samarinda Terhadap Sertipikat Hak Tanggungan Yang Hilang}

Sebagaimana telah dikemukakan sebelumnya Hak Tanggungan Wajib didaftarkan pada Kantor Pertanahan, hal ini sesuai dengan pada Pasal 13 ayat (1) Undang-undang No 4 tahun 1996. Pendaftaran Hak Tanggungan tersebut dilakukan di Kantor pertanahan setempat dengan membuat Buku Hak Tanggungan dan mencatatnya dalam buku tanah hak atas tanah yang menjadi obyek Hak Tanggungan tersebut pada Pasal 13 ayat (3) Undang-undang No. 4 tahun 1996 mengenai Hak Tanggungan. Sedangkan berlakunya dan lahirnya Hak Tanggungan itu adalah pada hari tanggal buku Hak Tanggungan tersebut (Pasal 13 ayat (5) Undang-undang Hak Tanggungan).

Mengingat Hak Tangggungan merupakan hak kebendaan, yaitu hak yang dapat dituntut oleh pemegang haknya dari pihak ketiga yang menguasai atau memiliki obyek Hak Taanggungan itu apabila obyek Hak Tanggungan semula, maka hapusnya Hak Tanggungan itu harus pula ditiadakan dari pencatatannya dibuku tanah Hak Tanggungan yang menjadi obyek Hak Tanggungan.

Didalam ketentuan Pasal 22 ayat (4) Undang-undang. Hak Tanggungan dinyatakan bahwa pencoretan dilakukan atas permohonan pihak yang berkepentingan dengan melampirkan sertipikat Hak Tanggungan yang telah diberi catatan oleh kreditur, bahwa Hak Tanggungan sudah lunas atau peryataan tertulis dari kreditur bahwa Hak Tanggungan sudah telah hapus karena piutangyang dijamin pelunasannya dengan Hak Tanggungan itu telah lunas atau karena kreditur melepaskan Hak tanggungan yang bersangkutan.

Pencoretan Hak Tanggungan dapat dilakukan dalam hal :

b. Perintah Ketua Pengadilan Negeri atas permohonan pihak yang berkepentingan apabila kreditur bersedia memberikan pernyataan (Pasal 22 ayat (5) UUHT).

c. Peryataan Roya sebagian/parsial apabila diperjanjikan pelunasan utang dilakukan dengan cara angsuran (Pasal 22 (9) Undang-undang Hak Tanggungan. 
d. Obyek Hak Tanggungan dilelang atau dijual melalui/secara dibawah tangan (Pasal 6 jo Pasal 20 ayat (2) Undang-undang Hak Tanggungan)

Berdasarkan Peraturan Pemerintah Nomor 24 tahun 1997 pencatatan hapusnya Hak Tanggungan dilakukan pada sertipikat maupun buku tanah hak atas tanah yang dibebani. Hal ini ditegaskan pula dalam ketentuan pasal 22 ayat (1) Undang-undang Hak Tanggungan bahwa dengan hapusnya Hak tanggungan, maka Kepala Kantor Pertanahan mencoret catatan Hak Tanggungan tersebut pada buku tanah ha katas tanah dan sertipikattnya.

Pencoretan catatan Hak Tanggungan dilakukan dalam 7 (tujuh) hari kerja terhitung sejak diterimanya permohonan pencoretan (Pasal 22 ayat (8) Undangundang Hak Tanggungan (UUHT). Dengan hapusnya Hak Tanggungan, maka sertipikat hak Tanggungan yang bersangkutan ditarik dan bersama-sama buku tanah Hak Tanggungan dinyatakan tidak berlaku lagi. Sertipikat Hak Tanggungan yang sudah diroya dimusnahkan/ditiadakan.

Aspek hukum yang timbul dari penghapusan Hak Tanggungan (Roya) terhadap sertipikat tanahnya adalah bahwa dengan adanya penghapusan Hak Tanggungan/Roya terhadap sertipikat tanahnya, maka hal ini akan diketahui oleh umum dan masyarakat akan tahu bahwa tanah yang telah dibebankan tadi telah bebas dan kembali dalam keadaan yang semula. Selain itu roya tersebut dilakukan demi ketertiban administrasi dan tidak mempunyai pengaruh hukum terhadap Hak Tanggungan yang sudah hapus. Dan apabila sertipikat hak atas tanah tersebut tidak segera dihapus/diroya, maka sertipikat ha katas tanah masih atas nama pihak kreditur (bank), maka pemilik sertipikat ha katas tanah tidak bisa melakukan perbuatan hukum, sebelum sertipikat ha katas tanah tersebut dihapus/diroya.

Sedangkan permasalahan yang timbul dalam praktek dilapangan dari hasil penelitian penghapusan Hak Tanggungan /Roya, bila dikaitkan dengan berlakunya Undang-undang Hak tanggungan adalah dalam Hal Sertipikat Hak Tanggungan Hilang seperti yang disebutkan diatas bahwa salah satu syarat melakukan penghapusan Hak Tanggungan/Roya adalah harus dilampirkan sertipikat Hak Tanggungan. Apabila tidak dilampirkan, maka Hak Tanggungan tersebut tidak dapat di Roya. Hal ini penting dikarenakan apabila hutang yang dijamin dengan Hak tanggungan telah lunas dibayar oleh pihak debitur, maka sertipikat Hak Tanggungan tersebut akan dimusnahkan oleh Kantor Pertanahan.

Berkenaan dengan hal tersebut masalah yang timbul adalah bagaimana apabila sertipikat Hak Tanggungan hilang. Dapatkah sertipikat Hak tanggungan yang hilang diganti dengan sertipikat Hak tanggungan yang baru sebagaimana mengganti sertipikat tanah yang baru, yang prosedurnya diatur dalam pasal 57 Peraturan Pemerintah Nomor 24 tahun 1997. Sertipikat Hak Tanggungan disamping diperlukan sebagai salah satu persyaratan pencoretan, diperlukan pula untuk kepentingan eksekusi Hak Tanggungan yang bersangkutan.

Apabila sertipikat Hak Tanggungan hilang, tidak berarti bahwa akan diganti dengan Sertipikat Hak Tanggugan yang baru, sebagaimana ketentuan yang mengatur tentang hilangnya sertipikat ha katas tanah. Menurut ketentuan Pasal 59 Peraturan Pemerintah Nomor 24 tahun 1997, apabila sertipikat ha katas tanah hilang, atas permohonan pemegang ha katas tanah diterbitkan sertipikat baru sebagaimana pengganti sertipikat yang hilang. Sebelum diganti dengan sertipikat yang baru, harus memasang pengumuman satu kali dalam surat kabar, kemudian permohonan penggantian permohonan penggantian sertipikat yang hilang harus 
disertai dengan pernyataan dibawah sumpah dari yang bersangkutan dihadapan kepala Kantor Pertanahan.

Mengenai sertipikat Hak Tanggungan yang hilang tidak ditempuh cara sebagaimana tersebut diatas. Apabila sertipikat Hak Tanggungan hilang, maka pihak yang bersangkutan, harus melapor polisi. Kemudian polisi akan membuat surat keterangan hilang dari Kantor polisi setempat. Selanjutnya pihak yang bersangkutan menghadap Kepala Kantor Pertanahan setempat untuk membuat surat pernyataan mengenai hilangnya sertipikat Hak Tanggugan tersebut, dengan membawa surat keterangan hilang dari kepolisian tadi disertai dengan surat permohonan dari pihak kreditur untuk dimohonkan roya serta surat lainnya misalnya identitas para pihak. Apabila semua persyaratan telah dipenuhi oleh yang berkepentingan, maka Kantor pertanahan segera melakukan roya/penghapusan Hak Tanggugan yang bersangkutan.

\section{BAB IV \\ PENUTUP}

\section{A. Kesimpulan}

Berdasarkan uraian di dalam pembahasan pada bab - bab terdahulu, maka dapat disimpulkan :

1. Pertangungjawaban kreditur (bank) terhadap pihak debitur dalam pergantian sertipikat hak tanggungan yang hilang. Maka pihak Kreditur Wajib menguruskan surat keterangan kehilangan dikantor kepolisian dan pihak kreditur wajib mengembalikan hak yang telah ditimbulkan oleh kreditur tanpa membebani pihak debiitur. Yang menjadi dasar hukum apabila kreditur tidak bertanggung jawab atas hilangnya sertipkat hak tanggungan maka debitur dapat meminta pertanggung jawaban pidana Korporasi dimana diatur dalam Undang-undang Perlindungan Konsumen nomor 8 tahun 1999

2. Proses pelaksanaan roya dikantor Pertanahan Kota Samarinda sudah sesuai dengan ketentuan pasal 22 (ayat 1) undang-undang no 4 tahun 1996 tentang hak tanggungan atas tanah besrta benda-benda yang berkaitan dengan tanah yaitu pihak yang bersangkutan menghadap Kepala Kantor Pertanahan setempat untuk membuat surat pernyataan mengenai hilangnya sertipikat Hak Tanggugan tersebut, dengan membawa surat keterangan hilang dari kepolisian tadi disertai dengan surat permohonan dari pihak kreditur untuk dimohonkan roya serta surat lainnya misalnya identitas para pihak. Apabila semua persyaratan telah dipenuhi oleh yang berkepentingan, maka Kantor pertanahan segera melakukan roya/penghapusan Hak Tanggugan yang bersangkutan.

\section{B. Saran}

Berdasarkan kesimpulan yang diuraikan di atas, maka akan diberikan saran-saran bagi berbagai pihak berkaitan dengan pelaksanaan roya terhadap sertipikat hak tanggungan roya yang hilang, sebagai berikut :

1. Pihak pemerintah, lebih memperhatikan kegiatan dari bank-bank terutama bagi Bank Indonesia sebagai pembina dan pengawas terhadap kegiatan perbankan agar dalam hal ini pihak bank lebih bertanggungjawab dan memperhatikan apa yang menjadi hak-hak dari pihak nasabah dan apabila 
bank-bank pelaksana melalaikan kewajiban dan tanggungjawab maka perlu ada sanksi yang tegas terhadap bank tersebut.

2. Pihak kreditur (bank) dalam hal ini selaku pemegang Hak Tanggungan agar lebih meningkatkan keamanan dan ketelitian dalam pengelolaan dokumendokumen khususnya yang menyangkut aset bank agar dikemudian hari kasus seperti ini tidak terjadi lagi sehingga kedua belah pihak yaitu kreditur (bank) mapun debitur tidak dirugikan.

3. Pihak debitur (nasabah) agar lebih menyegerakan pelaksanaan roya atas sertipikat hak atas tanahnya ketika pembayaran kepada pihak kreditur (bank) telah lunas, sehingga dapat meminimalisir terjadinya kehilangan sertipikat hak tanggungan ketika proses roya akan dilakukan.

4. Hendaknya Kantor Pertanahan Kota Samarinda perlu melakukan penyuluhan kepada pihak-pihak terkait perihal proses pelaksanaan roya apabila terjadi kehilangan pada sertipikat hak tanggungannya, sehingga semua pihak dapat segera mengetahui dan melengkapi hal-hal yang dipersyaratkan pada pelaksanaan roya sertipikat hak tanggungan yang hilang.

\section{DAFTAR PUSTAKA}

\section{A. Daftar Buku :}

Andrian Sutedi,SH.,MH, Hukum Hak Tanggungan, Penerbit Sinar Grafika, Jakarta, cet. II, 2012.

Abdullah Faisal. M, Drs. Manajemen Perbankan (Teknik Analisis Kinerja Keuangan Bank), Penerbit Universitas Muhamadiyah Malang, 2004

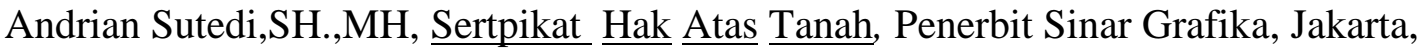
cet I, 2011

Abdul Kadir Muhammad, S,H. Prof., Hukum Perdata Indonesia, Penerbit PT. Citra Aditya Bakti, Bandung, cet. Revisi, 2010

Andreas Albertus Andi Prajitno, S.H.,M.Kn.,Drs. Hukum Fidusia, Penerbit Selaras, Surabaya, cet. I, 2010

Bahsan.,M.,S.H.,S.E., Hukum Jaminan dan Jaminan Kredit Perbangkan Indonesia, Jakarta, cet.II, 2010.

Bahder Johan, SH.,SM.,M.Hum.,DR., Metode Penelitian Hukum, Penerbit. Mandar Maju, Bandung, Cet.I, 2010.

Gazali, Djono S dan Rachmadi Usman, Hukum Perbankan, Penerbit Sinar Grafika, Jakarta, . cet. II, 2010.

HS. Salim. SH.,M.S.,Dr.,H.,Perkembangan Hukum Jaminan Di Indonesia, Penerbit RajaGrafindo Persada, Jakarta, cet.II, 2012.

Kartini Muljadi dan Gunawan Widjaja, Hak Tanggugan, Penerbit Kencana Prenada Media Group, Jakarta, cet.II, 2006.

Kartini Muljadi dan Gunawan Widjaja, Hak - Hak atas Tanah, Penerbit Kencana Prenada Media Group, Jakarta, cet.VI, 2012

Soejono.,S.H.,M.H, dan Abdurahman.,S.H.,M.H.,H., Prosedur Pendaftaran Tanah, Penerbit Rineka Cipta, Jakarta, cet.II, 2003

Santoso Az.,Lukaman., Hak dan Kewajiban Nasabah Bank, Penerbit Pustaka Yustisia, Yogyakarta,cet.II, 2011. 
Soejono Soekanto., S.H.,M.H.,Prof.,Dr. dan Sri Mamudji., S.H., M.L.L, Penelitian Hukum Normatif, Penerbit PT. Raja Grafindo Persada, Jakarta, cet. XIII, 2011.

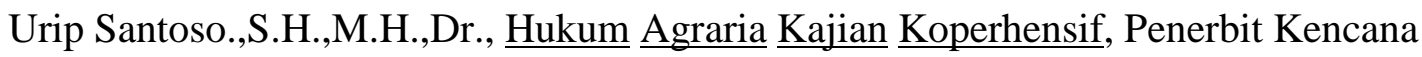
Media Group, Jakarta. Cet.II, 2013.

\section{B. Daftar Perundang-Undangan :}

- Republik Indonesia, Undang-Undang Dasar Negara Republik Indonesia tahun 1945

- Republik Indonesia, Undang-Undang No. 5 Tahun 1960 tentang Peraturan Dasar Pokok-pokok Agraria.

- Republik Indonesia, Undang-Undang No. 4 Tahun 1996 tentang Hak Tanggungan atas Tanah beserta Benda-benda yang berkaitan dengan Tanah.

- Republik Indonesia, Undang-Undang No. 8 Tahun 1999 tentang Perlindungan Konsumen

- Republik Indonesia, Kitab Undang-undang Hukum Perdata.

- Republik Indonesia, Peraturan Pemerintah No.24 tahun 1997 tentang Pendaftaran Tanah. 